ORIGINAL ARTICLE / ARTIGO ORIGINAL

\title{
The study of the mother-child binomium: description and general results
}

\section{O estudo do binômio mãe-filho: descrição e resultados gerais}

\author{
Ruy Laurenti', Maria Helena Prado de Mello Jorge', Sabina Léa Davidson Gotlieb', \\ Bruno Zoca de Oliveiral, Elaine Cristina Pimentel"
}

\begin{abstract}
Objective: The present study investigated the characteristics of women during pregnancy/ immediate postpartum cycles and the product of their pregnancy. Method: Data collection was conducted for a period of three months in 2011, in six maternity hospitals in the State of São Paulo. The data were obtained in an interview with the women after the end of the pregnancy and collected from hospital records. The sample included 7,058 women hospitalized for abortion or childbirth in five hospitals from SUS (Unified Health System) and from only one hospital for private health insurance patients and their 6,602 conceptuses (live births and stillborns). Statistical analysis was based on $\chi^{2}$ tests, with a significance level of $\alpha=5 \%$. Results: It was observed that 6,530 women gave birth and 528 showed interruption of pregnancy. Regarding age, 1,448 were teenagers $(20.5 \%)$. There were no deaths during hospitalization and $99.8 \%$ of women received a medical discharge. Maternal morbidity in the current pregnancy was analyzed, showing urinary tract infection, anemia and excessive vomiting as the main problems. The rate of cesarean sections accounted for $31.1 \%$ and complications in childbirth and postpartum were shown, respectively, by 834 (12.8\%) and 265 (4.1\%) women. The characteristics of the conceptuses were also studied: gestation length $(9.3 \%$ of preterm among live births, and $68 \%$ among the stillborn); birth weight (underweight in $8.2 \%$ among live births, and $66 \%$ among the stillborn) and morbidity, measured by congenital anomalies and other diseases; these diseases were responsible for ICU stay, transfers to better-equipped hospitals (10 cases) and 37 deaths. Thirteen live births were still hospitalized at the end of the investigation.
\end{abstract}

Keywords: Pregnancy. Parturition. Postpartum Period. Live Birth. Stillbirth. Epidemiology.

'Public Health School at Universidade de São Paulo - São Paulo (SP), Brazil.

"School of Arts, Sciences and Humanities at Universidade de São Paulo - São Paulo (SP), Brazil.

Corresponding author: Maria Helena Prado de Mello Jorge. Departamento de Epidemiologia da Faculdade de Saúde Pública da Universidade de São Paulo. Avenida Dr. Arnaldo, 715, CEP: 01246-904, São Paulo, SP, Brasil. E-mail: mhpjorge@usp.br

Conflict of interests: nothing to declare - Financial support: São Paulo Research Foundation (FAPESP), Project 09/53253-8. 
RESUMO: Objetivo: A pesquisa estudou as características de mulheres no ciclo gravídico/puerperal imediato e do produto de sua gestação. Método: A coleta dos dados, relativos a três meses, em 2011, foi feita em seis maternidades do Estado de São Paulo. Os dados foram obtidos em entrevista com a mulher após o desfecho da gestação e coletados nos prontuários hospitalares. Participaram 7.058 mulheres internadas por aborto ou parto em cinco hospitais do SUS e um, somente, para pacientes de convênio privado, e seus 6.602 conceptos (nascidos vivos e nascidos mortos). A análise estatística baseou-se em testes $\chi^{2}$, com nível de significância $\alpha=5 \%$. Resultados: Observou-se que 6.530 mulheres tiveram parto e 528 apresentaram interrupção da gestação. Quanto à idade, 1.448 eram adolescentes $(20,5 \%)$. Não ocorreu óbito durante a internação e 99,8\% das mulheres receberam alta médica. Morbidade materna na gestação atual foi analisada, aparecendo infecção urinária, anemia e vômitos exagerados como os principais problemas. A taxa de cesáreas correspondeu a 31,1\% e intercorrências no parto e puerpério apresentaram-se, respectivamente, em $834(12,8 \%)$ e 265 mulheres (4,1\%). Estudaram-se características dos conceptos: duração de gestação (9,3\% de pré-termo, entre os nascidos vivos, e $68 \%$, entre os nascidos mortos); peso ao nascer (baixo peso em $8,2 \%$, entre os nascidos vivos, e $66 \%$, entre os nascidos mortos) e morbidade, medida pelas anomalias congênitas e outras patologias; esses agravos foram responsáveis por permanência em UTI, transferências para hospital de maior complexidade (10 casos) e 37 óbitos. Treze nascidos vivos ainda permaneciam internados ao término da investigação.

Palavras-chave: Gravidez. Parto. Período pós-parto. Nascimento vivo. Natimorto. Epidemiologia.

\section{INTRODUCTION}

The improvement of human health has long-standing been a goal to be achieved in the world. In the 1970s, the World Health Organization (WHO) called attention to the program "Health for All by the Year 2000"1, which first considered necessary the reduction of infant death and the death of women - preventable events, in most cases. Despite its decline, in the beginning of this century the United Nations established the Millennium Development Goals (MDGs), among which the reduction of maternal and infant death continued to figure in as highly desired ${ }^{2}$. Brazil was one of the countries that signed the commitment to reach, until 2015, the eight objectives; among them, to reduce maternal mortality by three quarters in relation to the rates from $1990^{3}$. In this country, these two indicators are still high, although the infant death rate is in obvious decline and the maternal rate remains, in a certain way, steady. Their figures differ among the regions, revealing important aspects concerning existing inequalities and those aggravated by factors such as availability of resources, access to prenatal, birth and postpartum health services, which are not always reliable.

The Interagency Network of Health Information (RIPSA) has shown such figures ${ }^{4}$ and has been striving to improve the quality of information, considered essential for the diagnosis of health conditions and the evaluation of the actions put into practice in order to obtain improvement. However, even when the official data of infant and maternal death are considered good, they are not sufficient to plan for actions that aim at preventing these 
deaths. A study was then proposed, titled "Study of the mother-child binomium: an imperial necessity to reach the MDGs", subdivided into: I. Maternal morbidity and mortality and the product of pregnancy and its characteristics and II. The quality of information concerning vital events. The objective of the study was to learn about data related to situations that occurred with a woman in the pregnancy and immediate postpartum period and a few characteristics of the product of pregnancy (live birth, stillbirth and abortion, according to international concepts).

In this paper, the methods and general results for sub-project I have been described.

\section{MATERIAL AND METHODS}

The study included 7,058 women who were hospitalized for either an abortion or delivery during three months in the second half of 2011 in six maternity watrds in the state of São Paulo (ESP), four in the capital (São Paulo City) and two in the countryside (Bauru and Jundiai). Regarding hospitals, five were exclusive for patients using SUS (Unified Health System) $(6,873)$ and only one was a hospital for private health insurance patients $(n=185)$.

It is an investigation and, although the results refer to a large number of women and their conceptuses, they do not represent the population of ESP, since sampling techniques were not used to reach such results. The choice of hospitals depended upon the interest of their directors in participating. The data was collected directly, through interviews with the women, as well as from medical files and other hospital records and the prenatal card.

Answers were taken inserted in a specific form and data collection took place after the women had signed the informed consent form and the hospitals had given their formal agreement. The interviews were conducted by health professionals and it is important to note that the number of refusal/non-responses was insignificant ( 9 cases).

Sociodemographic variables were collected (age, schooling, employment status, marital status), personal history of specific morbidity, habits (smoking, alcohol and drugs), occurrence of violence during pregnancy, previous and current pregnancy history (prenatal care including number of appointments and in which month it began).

Regarding the conceptus, the variables were: sex, birth weight, type of delivery, type of conceptus, presence of congenital anomalies and other diseases (according to records in the medical files), use of ICU and type of discharge.

To process the data, the ABBYY FlexiCaptur e ${ }^{\mathrm{TM}}$ software (via scanner) was used, automatically converting the exportable data to any database application. The cases were exported to Microsoft Excel ${ }^{\mathrm{TM}}$.

For statistical analysis, the $\chi^{2}$ test (software Epi Info 6 version $6.04 \mathrm{~d}$ ) was used. Maternal age at the moment of hospitalization was defined as an independent variable, and the remaining data as dependent. The tests revealed whether the differences observed were random or statistically significant, at a level of $\alpha=5 \%$. 
The project, financed by FAPESP, was approved by The Research Ethics Commission at the Public Health School of Universidade de São Paulo and by the selected hospitals.

\section{RESULTS}

The total number of cases was 7,058 women and 6,602 conceptuses: 6,503 (92.5\%) women gave birth; 489 (6.9\%), had an abortion; 35 (0.5\%), had ectopic pregnancies and $4(0.1 \%)$, had hydatidiform mole. As for the type of pregnancy, 6,460 (98.9\%) were single pregnancies, $68(1.1 \%)$ were twins and $2(0.0 \%)$, triplets. There were no maternal deaths during hospitalization, being that 7,043 $(99.8 \%)$ were discharged, $8(0.1 \%)$ were transferred to a more complex institution and $7(0.1 \%)$ evaded the hospital (Figure 1$)$.

When sociodemographic characteristics of the women were observed, it was noted that $20.5 \%$ were teenagers (10 to 19 years old), $69.3 \%$ were between the ages of 20 and 34 and $10.2 \%$ were 35 or older. Regarding education, $46.3 \%$ completed high school, $30.9 \%$ completed elementary school and $15.5 \%$ had incomplete elementary school; $3.5 \%$ of the women had higher education and only $0.1 \%$ were illiterate. With reference to occupation, $48.7 \%$ were homemakers, $44.1 \%$ were working, $3.5 \%$ were unemployed and $2.3 \%$ were students. Concerning their living situation, $1.4 \%$ were living alone, $2.8 \%$, with their children, $76.1 \%$, with their husband/partner, and $18.8 \%$ with family members. The percentage $(60 \%)$ of teenagers that reported they were living with a husband/partner was statistically lower than the other age groups $(\mathrm{p}<0.001)$.

The obstetric history of the 7,058 women revealed $41.4 \%$ to be primigravidas, $43.8 \%$ to have had two or three previous pregnancies, $11.8 \%$ declared having had 3 or 4 pregnancies, and $3 \%, 5$ or more. It is interesting to observe that, analyzing this variable according to the age of the women, it was noted that $79.8 \%$ of teenagers, $34.7 \%$ of the women between the ages of 20 and 34 and $9.9 \%$ of the elder women were in their first pregnancy. Among the primigravidas, around $20 \%$ declared they had had health problems in previous pregnancies, $6 \%$ had complications after delivery and $5.7 \%$ had postpartum depression. The use of contraceptives before the current pregnancy was declared by $28.2 \%$ of the women and $32.4 \%$ planned this pregnancy.

Regarding some habits during the current pregnancy, smoking (14.1\%) and the use of alcohol $(10.7 \%$ of the women) stood out. The rates increased with age $(\mathrm{p}<0.001)$. The use of drugs was confirmed by $1.4 \%$ of the women and there was no association with age; $10.6 \%$ of the women declared some sort of accident (mostly falls) and $3.2 \%$ declared violence, including physical and emotional.

It was observed that $5.5 \%$ of the women did not undergo prenatal care, there being a significant difference according to age (4.4\% among teenagers and $10.2 \%$ in the case of the elder women). Approximately $60 \%$ attended at least seven appointments and it is fitting to point out, however, that the quality of the service and the professionals that treated them is unknown. 


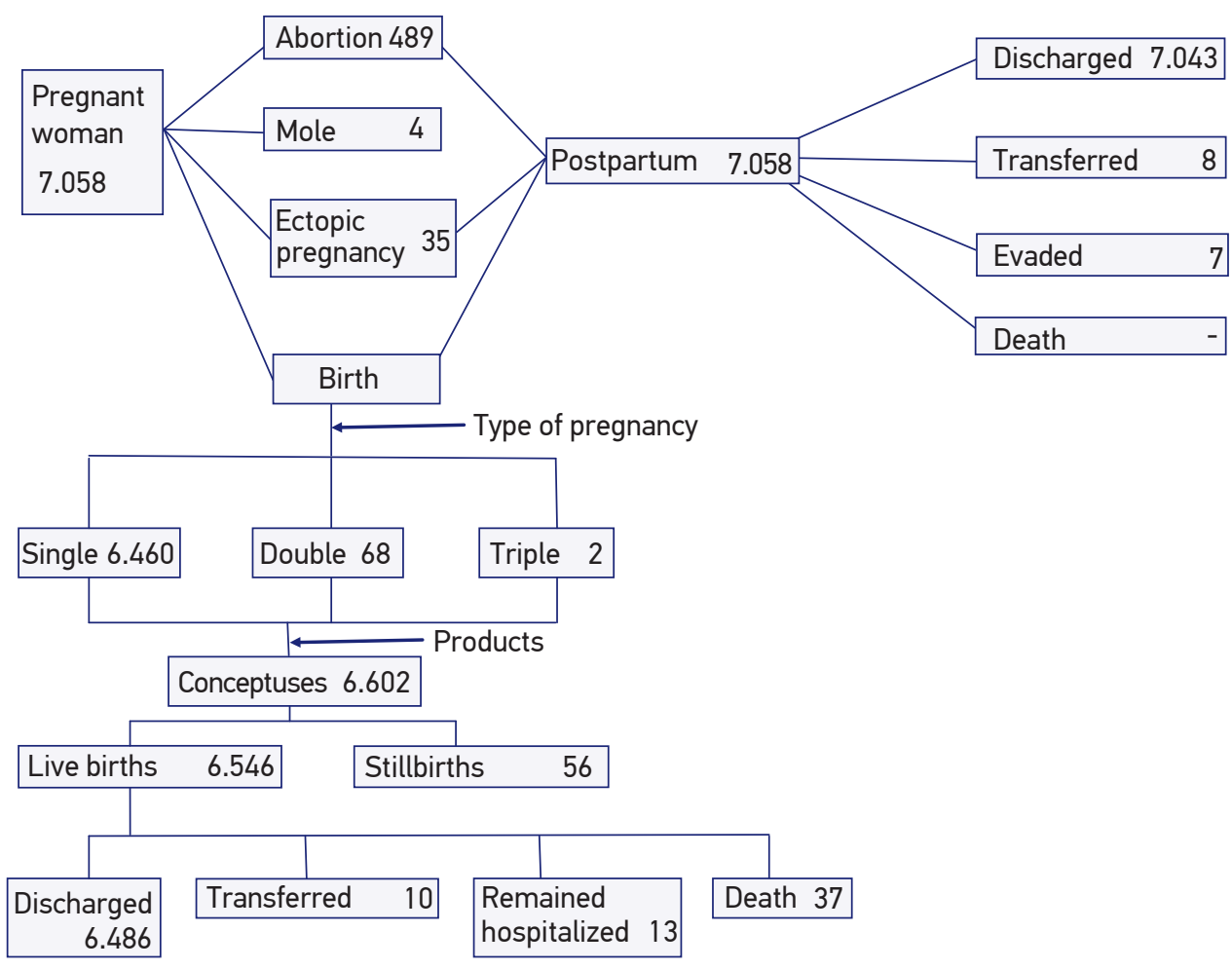

Figure 1. Scheme of the possible situations of women and their conceptsus from six hospitals, State of São Paulo, 2011.

Concerning maternal morbidity in the current pregnancy, in addition to the data registered in the medical forms, the women were asked if they had any health problem; 2,433 $(34.5 \%)$ declared they had not had any problems. Among those that answered positively, $4,591(60.5 \%)$ declared one to nine problems (Table 1$)$. The average number of diagnoses per woman was 1.14 and among the women with health problems it was 1.76 , varying according to hospital, with a minimum of 1.60 and a maximum of 2.19 diagnoses/women.

These problems were classified as suggested (read one by one to each interviewee) and reported (spontaneously, without being prompted). The suggested problems accounted for 6,357. Among them, urinary tract infection (29.7\%), anemia (13.2\%), excessive vomiting and high blood pressure in approximately $10 \%$ of the stated problems stood out. Among all the reported problems, 1,750 (21.6\%), the most frequent one was the infection by the Beta-hemolytic Streptococcus bacteria (419 women), followed by obesity (39 cases) and premature placenta detachment (34 cases) (Table 2). The women were asked if they sought out medical care/the need for hospitalization and $24.3 \%$ responded positively. Mostly, the causes were connected to the pregnancy itself $(21 \%)$, urinary tract infection and pain in 
Table 1. Number and proportion (\%) of women according to maternal age and number of health problems in the current pregnancy, from six hospitals in the State of São Paulo, 2011.

\begin{tabular}{|c|c|c|c|c|c|c|c|c|}
\hline \multirow{2}{*}{ Problems } & \multicolumn{2}{|c|}{10 to 19} & \multicolumn{2}{|c|}{20 to 34} & \multicolumn{2}{|c|}{$35+$} & \multicolumn{2}{|c|}{ Total } \\
\hline & $\mathrm{n}$ & $\%$ & $\mathrm{n}$ & $\%$ & $\mathrm{n}$ & $\%$ & $\mathrm{n}$ & $\%$ \\
\hline \multicolumn{9}{|l|}{ Yes (quantity) } \\
\hline 1 & 499 & 34.5 & 1,624 & 33.2 & 215 & 30.0 & 2,338 & 33.1 \\
\hline 2 & 290 & 20.0 & 977 & 20.0 & 156 & 21.8 & 1,423 & 20.2 \\
\hline 3 & 102 & 7.0 & 370 & 7.6 & 58 & 8.1 & 530 & 7.5 \\
\hline 4 & 28 & 1.9 & 138 & 2.8 & 34 & 4.8 & 200 & 2.8 \\
\hline 5 & 8 & 0.6 & 44 & 0.9 & 13 & 1.8 & 65 & 0.9 \\
\hline 6 & 3 & 0.2 & 15 & 0.3 & 2 & 0.3 & 20 & 0.3 \\
\hline 7 & - & - & 8 & 0.2 & 1 & 0.1 & 9 & 0.1 \\
\hline 8 & - & - & 2 & 0.0 & - & - & 2 & 0.1 \\
\hline 9 & - & - & 1 & 0.0 & - & - & 1 & 0.0 \\
\hline $\mathrm{n}$ ignored & 1 & - & 2 & 2.0 & - & - & 3 & 0.1 \\
\hline SUB-TOTAL & 931 & 64.3 & 3,181 & 65.0 & 479 & 66.9 & 4,591 & 65.0 \\
\hline No & 512 & 35.4 & 1,686 & 34.5 & 235 & 32.8 & 2,433 & 34.5 \\
\hline Ignored & 5 & 0.3 & 27 & 0.5 & 2 & 0.3 & 34 & 0.5 \\
\hline TOTAL & 1,448 & 100.0 & 4,894 & 100.0 & 716 & 100.0 & 7,058 & 100.0 \\
\hline
\end{tabular}

various locations. Complication during delivery and the postpartum period were noted, respectively, in $835(12.8 \%)$ and $265(4.1 \%)$ of women.

It is possible to note (Table 3 ) that, regardless of age, complications during delivery were represented mainly by: birth complications due to meconium in the amniotic fluid, dystocia and cephalopelvic disproportion. During the postpartum period, the highest rates occurred due to assistance given to the mother for reasons related to the fetus and the amniotic cavity and for possible problems related to the birth; among them we can point out hemorrhaging and assistance given to the mother for isoimmunization.

Regarding the outcome of the pregnancy, there were 528 (7.5\%) interruptions (women that had abortions, hydatidiform mole and ectopic pregnancy), leaving the remaining 6.530 to be classified as "deliveries", the products of which were either live births or stillborns. The percentage of interrupted pregnancies varied according to the age of the women. The figures were statistically different: 5.3\% among teenagers, $7.0 \%$ among those aged from 20 to 34 and $15.5 \%$ among those considered elderly. It was not possible to know if the abortion cases were spontaneous or induced, seeing that this is a difficult record to find in medical forms. 
Table 2. Number and proportion (\%) of problems in the current pregnancy according to type and maternal age, from six hospitals in the State of São Paulo, 2011.

\begin{tabular}{|c|c|c|c|c|c|c|c|c|}
\hline \multirow{2}{*}{ Problems } & \multicolumn{2}{|c|}{10 to 19} & \multicolumn{2}{|c|}{20 to 34} & \multicolumn{2}{|c|}{$35+$} & \multicolumn{2}{|c|}{ Total } \\
\hline & $\mathrm{n}$ & $\%$ & $\mathrm{n}$ & $\%$ & $n$ & $\%$ & $\mathrm{n}$ & $\%$ \\
\hline \multicolumn{9}{|l|}{ Suggested } \\
\hline Threat of abortion & 27 & 1.7 & 119 & 2.1 & 19 & 2.1 & 165 & 2.0 \\
\hline Anemia & 255 & 16.4 & 716 & 12.7 & 98 & 10.7 & 1,069 & 13.2 \\
\hline Seizure attacks & 3 & 0.2 & 6 & 0.1 & 3 & 0.3 & 12 & 0.1 \\
\hline Diabetes & 17 & 1.1 & 165 & 2.9 & 72 & 7.8 & 254 & 3.1 \\
\hline Prolonged pregnancy & 8 & 0.5 & 27 & 0.5 & 5 & 0.5 & 40 & 0.5 \\
\hline Hemorrhaging/bleeding & 76 & 4.9 & 360 & 6.4 & 60 & 6.5 & 496 & 6.1 \\
\hline Hepatitis & 3 & 0.2 & 21 & 0.4 & 5 & 0.5 & 29 & 0.4 \\
\hline Urinary tract infection & 561 & 36.1 & 1,659 & 29.5 & 184 & 20.0 & 2,404 & 29.7 \\
\hline HIV/AIDS infection & 6 & 0.4 & 22 & 0.4 & 3 & 0.3 & 31 & 0.4 \\
\hline High-blood pressure & 92 & 5.9 & 492 & 8.7 & 144 & 15.6 & 728 & 9.0 \\
\hline Syphilis & 14 & 0.9 & 54 & 1.0 & 11 & 1.2 & 79 & 1.0 \\
\hline Toxoplasmosis & 17 & 1.1 & 31 & 0.5 & 5 & 0.5 & 53 & 0.6 \\
\hline Varicose/thromboses & 10 & 0.7 & 84 & 1.5 & 17 & 1.9 & 111 & 1.4 \\
\hline Worms & 5 & 0.3 & 9 & 0.2 & 1 & 0.1 & 15 & 0.2 \\
\hline Excessive vomiting & 176 & 11.3 & 608 & 10.8 & 87 & 9.5 & 871 & 10.7 \\
\hline Sub-total & 1,270 & 81.7 & 4,373 & 77.7 & 714 & 77.5 & 6,357 & 78.4 \\
\hline Reported & 285 & 18.3 & 1,258 & 22.3 & 207 & 22.5 & 1,750 & 21.6 \\
\hline Total & 1,555 & 100.0 & 5,631 & 100.0 & 921 & 100.0 & 8,107 & 100.0 \\
\hline
\end{tabular}

The caesarians constituted a total of $31.1 \%$ of deliveries, there being, however, significant statistic differences $(\mathrm{p}<0.001)$ among the rates, due to age as well as outcome (Table 4).

No deaths were reported among the women. However, due to medical complications, ICU care was necessary in 31 of the cases and seven women had to be transferred to betterequipped hospitals.

The 6,602 conceptuses corresponded to $56(0.8 \%)$ stillbirths (SB) and 6,546 (99.2\%) live births (LB). In both cases, there was a predominance of boys, with a gender ratio of 206.3, and 107.0 males for every 100 females, respectively.

The birth weight differed among SB and LB (64.3\% of SB weighed up to $2,499 \mathrm{~g}$, a rate which, among LB, was $8.2 \%$ ). It was noted that, among SBs, in almost $68 \%$ of the cases 
Table 3. Number and proportion (\%) of mothers with health problems in child birth and postpartum period according to cause, from six hospitals in the State of São Paulo, 2011.

\begin{tabular}{l|c|c|c|c|}
\multirow{2}{*}{ Causes } & \multicolumn{2}{|c|}{ Birth } & \multicolumn{2}{c}{ Postpartum period } \\
\cline { 2 - 5 } & $\mathrm{n}$ & $\%$ & $\mathrm{n}$ & $\%$ \\
\hline
\end{tabular}

Maternal causes*

\begin{tabular}{|c|c|c|c|c|}
\hline ००० to 008 & - & - & 1 & 0.4 \\
\hline 010 to 016 & 38 & 4.1 & 34 & 12.4 \\
\hline 020 to 029 & 7 & 0.8 & 19 & 6.9 \\
\hline 030 to 048 & 99 & 10.7 & 16 & 5.9 \\
\hline 060 to 075 & 607 & 65.6 & 58 & 21.3 \\
\hline 080 to 084 & 2 & 0.2 & - & - \\
\hline 085 to 092 & 2 & 0.2 & 27 & 9.9 \\
\hline 094 to 099 & 4 & 0.4 & 30 & 11.0 \\
\hline Sub-total & 759 & 82.0 & 185 & 67.8 \\
\hline \multicolumn{5}{|l|}{ Other natural causes ${ }^{* *}$} \\
\hline Infectious Diseases & 150 & 16.2 & 3 & 1.1 \\
\hline Neoplasms & 1 & 0.1 & - & - \\
\hline Endocrine Diseases & 1 & 0.1 & 1 & 0.4 \\
\hline Mental Disorders & 2 & 0.2 & 7 & 2.6 \\
\hline Diseases of the Nervous System & - & - & 2 & 0.7 \\
\hline Diseases of the Circulatory System & - & - & 1 & 0.4 \\
\hline Diseases of the Respiratory System & 1 & 0.1 & 2 & 0.7 \\
\hline Diseases of the Digestive System & - & - & 1 & 0.4 \\
\hline Diseases of the Skin and Subcutaneous Tissue & - & - & 6 & 2.2 \\
\hline Diseases of the Genitourinary System & 2 & 0.2 & - & - \\
\hline Ill-defined & 10 & 1.1 & 65 & 23.8 \\
\hline Sub-total & 167 & 18.0 & 88 & 32.2 \\
\hline Total ${ }^{\star \star *}$ & 926 & 100.0 & 273 & 100.0 \\
\hline
\end{tabular}

*According to the grouping in Chapter XV of the ICD-10 - Causes realted to prenancy, birth and postpartum period.

${ }^{* *}$ According to chapters I to XIV and XVI to XVIII of ICD-10.

***000 to 008 - Pregnancy with abortive outcome; 010 to 016 - Oedema, proteinuria and hypertensive disorders in pregnancy, childbirth and the puerperium; 020 to 029 - Other maternal disorders predominantly related to pregnancy; 030 to 048 - Maternal care related to the fetus and amniotic cavity and possible delivery problems; 060 to 075 Complications of labour and delivery; 080 to 084 - Delivery; 085 to 092 - Complications predominantly related to the puerperium; 095 to 099 - Other obstetric conditions, not elsewhere classified. 
Table 4. Number and proportion (\%) of concepts according to maternal age, the type of outcome and type of delivery, from six hospitals in the State of São Paulo, 2011.

\begin{tabular}{|l|c|c|c|c|c|c|c|c|c|}
\multirow{2}{*}{$\begin{array}{l}\text { Type of outcome/ type of } \\
\text { delivery }\end{array}$} & \multicolumn{2}{|c|}{10 to 19} & \multicolumn{2}{|c|}{20 to 34} & \multicolumn{2}{c|}{$35+$} & \multicolumn{2}{c}{ Total } \\
\cline { 2 - 9 } & $n$ & $\%$ & $n$ & $\%$ & $n$ & $\%$ & $n$ & $\%$ \\
\hline Stillbirths & 2 & 12.5 & 3 & 10.7 & 2 & 16.7 & 7 & 12.5 \\
\hline Cesarean & 14 & 87.5 & 25 & 89.3 & 10 & 83.3 & 49 & 87.5 \\
\hline Vaginal & - & - & - & - & - & - & - & - \\
\hline Vaginal-forceps & 16 & 100.0 & 28 & 100.0 & 12 & 100.0 & 56 & 100.0 \\
\hline Sub-total & & & & & & & \\
\hline Live births & 323 & 23.6 & 1,445 & 31.6 & 280 & 46.3 & 2,048 & 31.3 \\
\hline Cesarean & 878 & 64.2 & 2,804 & 61.3 & 292 & 48.3 & 3,974 & 60.7 \\
\hline Vaginal & 166 & 12.2 & 325 & 7.1 & 33 & 5.4 & 524 & 8.0 \\
\hline Vaginal-forceps & 1,367 & 100.0 & 4,574 & 100,0 & 605 & 100.0 & 6,546 & 100.0 \\
\hline Sub-total & & & & & & & & \\
\hline Total & 325 & 23.5 & 1,448 & 31.5 & 282 & 45.7 & 2,055 & 31.1 \\
\hline Cesarean & 892 & 64.5 & 2,829 & 61.5 & 302 & 48.9 & 4,023 & 60.9 \\
\hline Vaginal & 166 & 12.0 & 325 & 7.0 & 33 & 5.4 & 524 & 8.0 \\
\hline Vaginal-forceps & 1,383 & 100.0 & 4,602 & 100.0 & 617 & 100.0 & 6,602 & 100.0 \\
\hline Total & & & & & & & \\
\hline
\end{tabular}

gestational age was below 37 weeks. Among those alive, the inverse occurred: $90.2 \%$ were the product of 37 week gestation or longer and 9.3\% were below this age.

The APGAR scale revealed that almost $90 \%$ of live conceptuses presented a score between 8 and 10 already in the $1^{\text {st }}$ minute of life, a rate that surpassed $97,7 \%$ when evaluated in the $5^{\text {th }}$ minute.

Congenital anomalies occurred in 274 conceptuses ( 5 among the SBs, with a prevalence of $8.9 \%$, and 269 among the LV, with a prevalence of $4.1 \%$ ). The presence of children with more than one anomaly was observed (on average, 2.2 per stillbirth and 1.2 per live birth), and most common ones were those of musculoskeletal system and genital organs. The existence of other health problems during birth or acquired during hospitalization was found in 1,682 (25.7\%) LV. These issues were responsible for the need to send them to the ICU (292 children), as well as transfer them to better-equipped hospitals (10). Thirtyseven deaths occurred in the same hospital of birth and 6,512 were discharged, while 13 remained hospitalized. 


\section{DISCUSSION}

Women at a fertile age and children up to one year of age represent an important portion of the country's population. The indicators related to this group, despite presenting significant improvement in the last years, are still responsible for high neonatal mortality rates and rates of maternal mortality, which are worrisome ${ }^{4}$. In this sense, it is worth stressing that, even with the decrease in the number of deaths resulting from causes related to pregnancy and postpartum cycles $^{5,6}$, Brazil still presents rates that are higher than those in other countries, and is unlikely to reach the goals of the MDGs. Perinatal mortality, in turn, equals to 14 for every 1,000 births in the state of São Paulo ${ }^{4}$, has its "stillbirth" component little studied and analyzed ${ }^{7,8}$. As a result, the study of the mother-child binomium proves itself relevant, as its objectives are more than what the official data is able to reveal, since they even seek to establish a relationship between characteristics and maternal components and their impact on the health of their children.

It is believed that the results of the investigation, although not based on sample techniques, represent a good approximation with reality. The analysis of the profile of the 7,058 women and their 6,602 conceptuses revealed known aspects, but also allowed evidence to arise regarding important aspects of which little is still known.

The high percentage of teenagers $(20.5 \%)$ stood out, since the percentage of mothers of live births, in the city of São Paulo, has been registered to be around $13.3 \%{ }^{9}$. Such a fact can be explained, seeing that:

1. the gestation in adolescence occurs, in general, in less developed areas ${ }^{10}$, and in this study the research was done almost only with the population treated by SUS. This hypothesis can be ratified by the fact that schooling among these women is a bit lower than what is stated for this age group, in São Paulo as a whole';

2. the population studied included hospitalization for abortion (7.5\%), of which a nonnegligible percentage was below the age of 20 .

In a study about the factors associated with perinatal morbimortality in Rio de Janeiro ${ }^{11}$, it was revealed that most teenage mothers are in leading institutions for high-risk pregnancies and in those connected to SUS in comparison to private hospitals that meet different levels of needs, a similar situation to the current investigation. It is important to point out that some authors report that teenage pregnancy is also related to poverty ${ }^{12}$.

Regarding the obstetric past of the women studied, $41.4 \%$ were primigravidas, a figure that was shown to be related to age. For teenagers, $17.1 \%$ had had a previous pregnancy, $2.6 \%$, two pregnancies; and four were on their fourth pregnancy. Official data for the country show a significant decline in fertility rates, which went from 6.3, in the early 1960s, to 1.8 children per women between 2002 and 2006. However, this shows that the decline has been much slower for women between the ages of 15 and 19 and shows the ascension in the 10 to 14 age group ${ }^{13,14}$. 
It was observed that smoking and drinking habits and the use of drugs were not abandoned even during pregnancy. Various surveys conducted in the country concerning tobacco and alcohol issues have shown an increasing participation of women in terms of frequency and amount of use ${ }^{15,16}$. In Rio de Janeiro ${ }^{11}$, the percentages were similar for tobacco and drugs; however, in regard to alcohol intake, the figures for São Paulo were inferior. Given the awareness of the deleterious effects of these habits on the conceptus, like higher risks for low weight during birth among smoking mothers ${ }^{17}$, this is an important aspect to be addressed during orientation for the pregnant woman.

Concerning prenatal care, its lack has been pointed out as a risk factor for the pregnancy, with important repercussions on the health of the woman and the child ${ }^{11,18}$. The study showed that a small portion (5.5\%) of women did not have any appointments; it was noted, however, that according to age, the percentage of pregnant women without prenatal care rises to $10.2 \%$ in the case of women who are 35 and older. This figure is compatible with what is found in the outcome of the pregnancy, since it was precisely among the older age group that the higher percentage of interrupted pregnancies was found $(14.1 \%)$, perhaps suggesting the occurrence of undesirable pregnancies. Also, it is important to stress that in the city of São Paulo there is an incentive for the use of prenatal care, which guarantees adequate referral in delivery care and even the distribution of layette sets for the newborns (Programa Mãe Paulistana, São Paulo Municipal Government).

The distribution of women according to the use of prenatal care and when it began revealed that, the younger the woman, the later the onset of treatment, a topic that has been discussed by other authors ${ }^{19}$. Seven or more prenatal appointments were verified in a high percentage of women. However, nothing is known about the quality of this care, a fact that has been stressed in the National Study of Demography and Health ${ }^{20}$.

The gestation is a physiological phenomenon and its evolution, in general, occurs without any complications. However, in a certain number of cases, health problems generally detected during prenatal care, complications during delivery or postpartum can occur and can represent some type of risk for the mother or for the child. Of the pathologies that can occur during a pregnancy, 1.76 was mentioned per woman, including suggested and reported conditions. Among the suggested problems, some stand out, such as urinary tract infection $(29.7 \%)$, which in many cases was proven through laboratory exams that appeared in medical records, and anemia (13.2\%). Regarding hypertension, this took up $9 \%$ of the problems, a figure similar to that of other authors ${ }^{11,21}$. Among the reported problems, which also appeared in medical records, was the positive result for Beta-hemolytic Streptococcus, a maternal infection that occurs in pregnancies; through vertical transmission during delivery, it can affect the conceptus, causing pathological manifestations. The Municipal Secretary of Health in São Paulo determines specific procedures, in order to prevent neonatal sepsis ${ }^{22}$.

Among the registered diagnoses in medical records related to delivery and postpartum complications, it was possible to consider the potentially severe ones and those suggestive of near miss cases, according to lists presented by different authors ${ }^{23,24}$. Here, it is important to stress that some of the pathologies, if not resulting in the death of any of the women 
while they were hospitalized in the same location where the outcome of their pregnancy occurred, were responsible for complications that generated the referral of 31 women to the ICU $(0.4 \%)$ and for seven $(0.1 \%)$ to be transferred to better-equipped hospitals. Subproject II, which is in progress, has already provided knowledge that one of the women transferred died soon after hospitalization in the institution she was taken to. The main cause was maternal death.

In regard to the conceptuses, the national and international criteria of live birth, stillbirth and abortion were adopted ${ }^{25,26}$ (sign of life, duration of pregnancy, weight and height of conceptus). It was observed that the definitions were, in general, used by the hospitals studied.

The distribution of conceptuses according to type - live birth and stillbirth - and sex revealed gender rates equal to 107.0, and 206.3 men for every 100 women, respectively. This predominance of the male gender in relation to the female is expected, since from conception more male fetuses are generated than female, while at the same time there is higher male mortality.

Birth weight is an important variable to evaluate the viability of the product, and low weight at birth (the cut off point for low weight is $2,500 \mathrm{~g}^{25}$ ) is seen as, perhaps, the most important factor in the study of neonatal morbimortality ${ }^{27,28,29}$. Low weight can be a result of prematurity and/or the restriction of intrauterine growth ${ }^{30}$. Victora et al. ${ }^{31}$ report, however, that "given the stability of the percentage of low weight when born in Brazil around $8 \%$, since 2000 , according to official data ${ }^{10}$ - a possible explanation for this fact is in the reduction of the frequency of intrauterine growth stunt, balancing, then, the negative effect of the increase in prematurity."

Among the stillbirth conceptuses, $64.3 \%$ presented low weight, probably due to low gestational age; among the live births, the percentage was at $8.2 \%$, a figure consistent with the official data ${ }^{10}$.

Prematurity, although not considered the main cause, according to international norms ${ }^{25}$, is recognized as an extremely important contributing factor to death. As for stillborns, in almost $70 \%$ the gestational age was lower than 37 weeks, coinciding, in the majority of cases, with low weight ${ }^{8}$.

Among the live births, premature delivery constitutes an import cause of infant death, especially during the neonatal period ${ }^{8,29}$. Regarding live births that died, premature delivery was present in $70.3 \%$ of cases.

It is important to note that, although cases of live births with extremely low weight that have survived have been registered, most conceptuses dies during the early neonatal period $^{28,29}$. The investigation showed that, of the 37 deaths that occurred, $28(75.7 \%)$ were of low weight.

As for the congenital anomalies, the percentage of cases with this pathology stood out: $8.9 \%$ among stillborns and $4.1 \%$ among live births. Comparing the figures to data from SINASC, only for live births, it can be verified that, in Brazil, the percentage is of $0.8 \%$ and, in São Paulo, where there is great incentive from the Municipal Secretary of Health seeking 
the improvement in the quality of information over this variable ${ }^{32}$, it can be seen that the official data is still under-reported (there is a prevalence of $1.5 \%$ for live births).

Concerning the type of birth, Patah and Malik ${ }^{32}$ report that the models for delivery assistance and the performance of caesarians has been debated since 1980 . Victora et al. ${ }^{31}$ go even further down this historic line, showing that the so called "epidemic" of caesarians named by Gentile de Melo - actually occurred in the 1970s, when there was a difference in the price for surgical and vaginal deliveries, making it clear that they occurred more frequently among women from privileged socioeconomic groups, who were white and had higher schooling ${ }^{11,33,34}$.

Various authors have shown that higher figures can be found in non-public hospitals. In this study, the caesarian rate was $31.1 \%$, ranging, however, according to:

1. type of conceptus ( $12.5 \%$ among the stillbirths and $31.3 \%$ when it was a live birth);

2. maternal age; and

3. type of hospital, since, in the only one that treated patients with private care and health insurance the rate was over $80 \%$.

Rattner et al. ${ }^{35}$ show that, in Brazil today, caesarians even vary according to the day of the week and the time of day. WHO established that the acceptable limit for operated deliveries is between 10 and $15 \%$, but Brazil is far from that goal. Here, there are surgeries performed without any maternal or fetal conditions that would even justify them ${ }^{35}$. Despite the public policies that seek to lower the rates of caesarians in the country and, specifically, in São Paulo, the year of 2009 registered, according to data from SINASC, 58.1\% of operated deliveries. Of the 6,546 live births, 6,486 were discharged (99.1\%); 10 were transferred and 37 died while still hospitalized in the same hospital where they were born; 13 still had not been discharged by the end of the study. The 10 cases that were transferred to better-equipped hospitals had a pathology which, in general, required surgery, and it was not possible to perform it in the institution where they were.

Among the deaths, 12 had basic congenital anomaly and 17 were premature; these were mostly due to a maternal cause. Regarding the age of death, of the 37 cases, 28 died during the early neonatal period, which allows for calculations of various indicators in the motherchild binomium.

\section{CONCLUSION}

The methodology utilized in this research allowed some new aspects related to the pregnancy and postpartum cycles to be shown, of which, even when the official data are considered to be good, cannot be known. Among these one can find problems connected to women's morbidity during pregnancy, complications during birth, the postpartum period and the needs for ICU.

Regarding the conceptuses, the study allowed for a deeper awareness of various topics, for example, the presence of congenital anomalies at birth (not stemming from DN) and other pathologies. 


\section{REFERENCES}

1. World Health Organization/United Nations Children's Fund (WHO/UNICEF). Report of the International Conference on Primary Health Care. Alma-Ata, USSR, 6-12 set., 1978. Geneva: WHO; 1978.

2. United Nations. Millenium Declarations. New York: UN; 2000

3. World Health Organization. Health and Millenium Development Goals. Geneva: WHO; 2005.

4. Rede Interagencial de Informações para a Saúde. Indicadores básicos para a saúde no Brasil - IDB 2011. Brasília: RIPSA; 2012.

5. World Health Organization. Beyond the numbers. Reviewing maternal deaths and complications to make pregnancy safer. Geneva: WHO; 2004.

6. Laurenti R, Mello Jorge MHP, Gotlieb SLD. Estudo de mortalidade de mulheres de 10 a 49 anos, com ênfase na mortalidade materna (Relatório final). Brasília: Ministério da Saúde; 2006 (Série C - Projetos, programas e relatórios).

7. Lansky S, França E, Leal MC. Mortalidade perinatal e evitabilidade: revisão de literatura. Rev Saúde Pública 2002; 36(6): 759-72.

8. Almeida MF, Alencar GP, Shoeps D, Minuci EG, Silva ZP, Ortiz LP, et al. Qualidade das informações registradas nas declarações de óbito fetal em São Paulo, SP. Rev Saúde Pública 2011; 45(5): 845-53.

9. Ministério da Saúde. DATASUS. Sistema de Informações sobre Nacidos Vivos - SINASC. Disponível em: www. datasus.gov.br.

10. Maranhão AGK, Vasconcelos AMN, Moura EC, ReyesLecca R. Como nascem os brasileiros: características epidemiológicas e sócio-demográficas dos nascimentos no Brasil de 2000 a 2010. In: Brasil. Ministério da Saúde. Secretaria de Vigilância em Saúde. Departamento de Análise de Situação de Saúde. Saúde Brasil 2011: uma análise da situação de saúde e a vigilância da saúde da mulher. Brasília: Editora MS; 2012. p. 13-27.

11. Leal MC, Gama SGN, Campos MR, Cavalini LT, Garbayo LS, Brasil CLP, et al. Fatores associados à morbi-mortalidade perinatal em uma amostra de maternidades públicas e privadas do Município do Rio de Janeiro, 1999-2001. Cad Saúde Pública 2004; 20(supl 1): S20-33.

12. Gama SGN, Szwarcwald CL, Leal MC, Theme Filha MM. Gravidez na adolescência como fator de risco para baixo peso ao nascer no Município do Rio de Janeiro, 1996 a 1998. Rev Saúde Pública 2001; 35(1): 74-80.

13. Instituto Brasileiro de Geografia e Estatística. Síntese de Indicadores Sociais. Uma análise das condições de vida da população brasileira. Rio de Janeiro: IBGE, 2010.
14. Simões CCS. A transição da fecundidade no Brasil: análise de seus determinantes e as novas questões demográficas. São Paulo: Arbeit Factor; 2006.

15. Laranjeira R, Pinsky I, Zaleski M, Caetano R. I Levantamento nacional sobre os padrões de consumo de álcool na população brasileira. Brasília: Secretaria Nacional Antidrogas; 2007.

16. Brasil. Ministério da Saúde. Secretaria de Vigilância em Saúde. Vigilância de Fatores de Risco e Proteção para Doenças Crônicas por Inquérito Telefônico. Ministério da Saúde. Secretaria de Vigilância em Saúde (VIGITEL) 2011. Brasília: Ministério da Saúde; 2012.

17. Mello PRB, Pinto GR, Botelho C. Influência do tabagismo na fertilidade, gestação e lactação. Jornal de Pediatria 2001; 77(4): 257-64.

18. Goldemberg P, Figueiredo MCT, Souza e Silva R. Gravidez na adolescência, pré-natal e resultados perinatais em Montes Claros, Minas Gerais, Brasil. Cad Saúde Pública 2005; 21(4): 1077-86.

19. Nascimento dos Santos GH, Martins MG, Souza MS. Gravidez na adolescência e fatores associados com baixo peso ao nascer. Rev Bras Ginecol Obstet 2008; 30(5): 224-31.

20. Brasil. Ministério da Saúde. Centro Brasileiro de Análise e Planejamento. Pesquisa Nacional de Demografia e Saúde da Criança e da Mulher (PNDS-2006). Brasília: Ministério da Saúde; 2009.

21. Granger JP, Alexander BT, Bennett WA, Khalil RA. Pathophysiology of pregnancy - induced hypertension. Am J Hypertens 2001; 14(6 Pt. 2): 178S-85S.

22. Brasil. São Paulo (SP). Secretaria Municipal de Saúde. Portaria 1149 de 03 de julho de 2009. Institui as normas para a prevenção da infecção neonatal por estreptococo beta hemolítico do grupo B. Diário Oficial da cidade de São Paulo, f1. 18.

23. Stones W, Lim W, Al-Azzawi F, Kelly M. An investigation of maternal morbidity with identification of life-threatening "near miss" episodes. Health Trends 1991; 23(1): 13-5.

24. Souza JPD, Cecatti JS, Parpinelli MA, Serruya SJ, Amaral E. Appropriate criteria for identification of near-miss maternal morbidity in tertiary care facilities: A cross sectional study. BMC Pregnancy Childbirth 2007; 7: 20.

25. Organização Mundial de Saúde. $10^{a}$ Revisão da Classificação Estatística Internacional de Doenças e Problemas Relacionados com a Saúde (CID-10). São Paulo: Centro Brasileiro de Classificação de Doenças; 1995.

26. Brasil. Ministério da Saúde. Conselho Federal de Medicina. A declaração de óbito: documento necessário e importante. Brasília: Centro Brasileiro de Classificação de Doenças; 2007. 
27. Monteiro CA, Benício MHA, Ortiz LP. Tendência secular do peso ao nascer na cidade de São Paulo, 1984-1996. Rev Saúde Pública 2000; 34(6): 26-40.

28. Assis HM, Machado CJ, Rodrigues RN. Perfis de mortalidade neonatal precoce: um estudo para uma maternidade pública de Belo Horizonte (MG), 20012006. Rev Bras Epidemiol 2008; 11(4): 675-86.

29. Almeida MF, Novaes HMD, Alencar GP, Rodríguez LC. Mortalidade neonatal no Município de São Paulo: influência do peso ao nascer e fatores sóciodemográficos e assistenciais. Rev Bras Epidemiol 2002; 5(1): 93-107.

30. Lawn JE, Cousens S, Zupan J. Lancet Neonatal Survival Steering Team. 4 million neonatal deaths: when? Where? Why? Lancet 2005; 365(9462): 891-900.

31. Victora CG, Aquino EM, Leal MC, Monteiro CA, Barros FC, Szwarcwald CL. Maternal and child health in Brazil: progress and challenges. Lancet 2011; 377(9780): 1863-76.
32. Patah LEM, Malik AM. Modelos de assistência ao parto e taxa de cesárea em diferentes paises. Rev Saúde Pública 2011; 45(1): 185-94.

33. Freitas PF, Drachler ML, Leite JC, Grassi PR. Desigualdade social nas taxas de cesariana em primíparas no Rio Grande do Sul. Rev Saúde Pública 2005; 39(5): 761-7.

34. Pádua KS, Osis MJD, Faundes A, Barbosa AH, Moraes Filho $\mathrm{OB}$. Fatores associados à realização de cesariana em hospitais brasileiros. Rev Saúde Pública 2010; 44(1): 70-9.

35. Rattner D, Rabello-Neto DL, Lansky S, Vilela MEA, Bastos MH. As cesarianas no Brasil: situação no ano de 2010, tendências e perspectivas. In: Saúde Brasil 2011. Brasília: Ministério da Saúde; 2012.

Received on: 12/05/2013

Final version presented on: 08/14/2014

Accepted on: 10/13/2014 